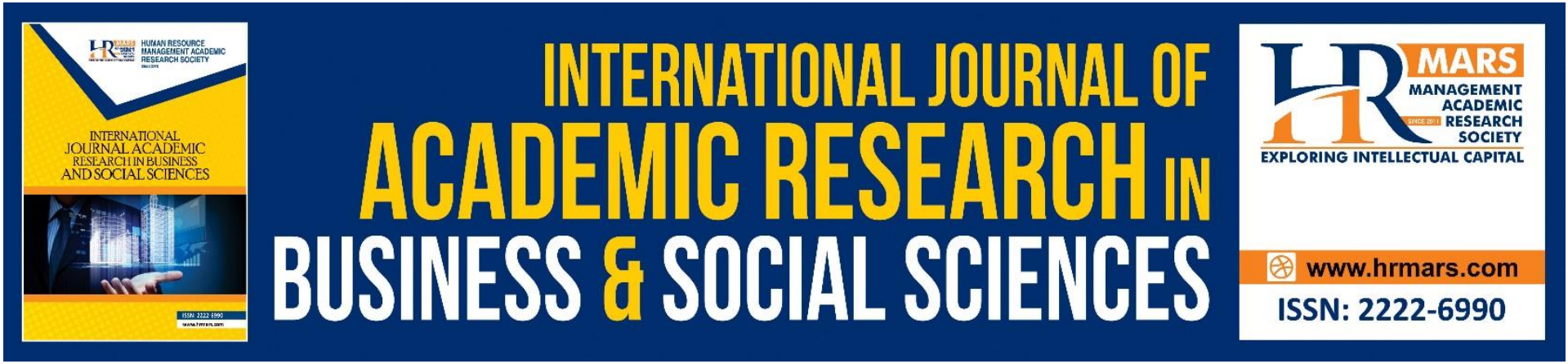

\title{
The Nexus of Pondok Pesanten and Quadruple Helix Approach to Enhance Local Capacity in Jember, Indonesia
}

\author{
Suyatno Ladiqi, Anas Mohd Yunus, Mohamad Zaidin Bin Mat @ Mohamad, \\ Najihah Binti Abd Wahid, Mohd. Shafiee Bin Hamzah
}

To Link this Article: http://dx.doi.org/10.6007/IJARBSS/v10-i11/8204

DOI:10.6007/IJARBSS/v10-i11/8204

Received: 02 October 2020, Revised: 22 October 2020, Accepted: 16 November 2020

Published Online: 29 November 2020

In-Text Citation: (Ladiqi et al., 2020)

To Cite this Article: Ladiqi, S., Yunus, A. M., Mohamad, M. Z. B. M. @, Wahid, N. B. A., \& Hamzah, M. S. Bin. (2020). The Nexus of Pondok Pesanten and Quadruple Helix Approach to Enhance Local Capacity in Jember, Indonesia. International Journal of Academic Research in Business and Social Sciences, 10(11), 1261-1267.

Copyright: (c) 2020 The Author(s)

Published by Human Resource Management Academic Research Society (www.hrmars.com)

This article is published under the Creative Commons Attribution (CC BY 4.0) license. Anyone may reproduce, distribute, translate and create derivative works of this article (for both commercial and non-commercial purposes), subject to full attribution to the original publication and authors. The full terms of this license may be seen at: http://creativecommons.org/licences/by/4.0/legalcode

Vol. 10, No. 11, 2020, Pg. 1261 - 1267

Full Terms \& Conditions of access and use can be found at http://hrmars.com/index.php/pages/detail/publication-ethics 


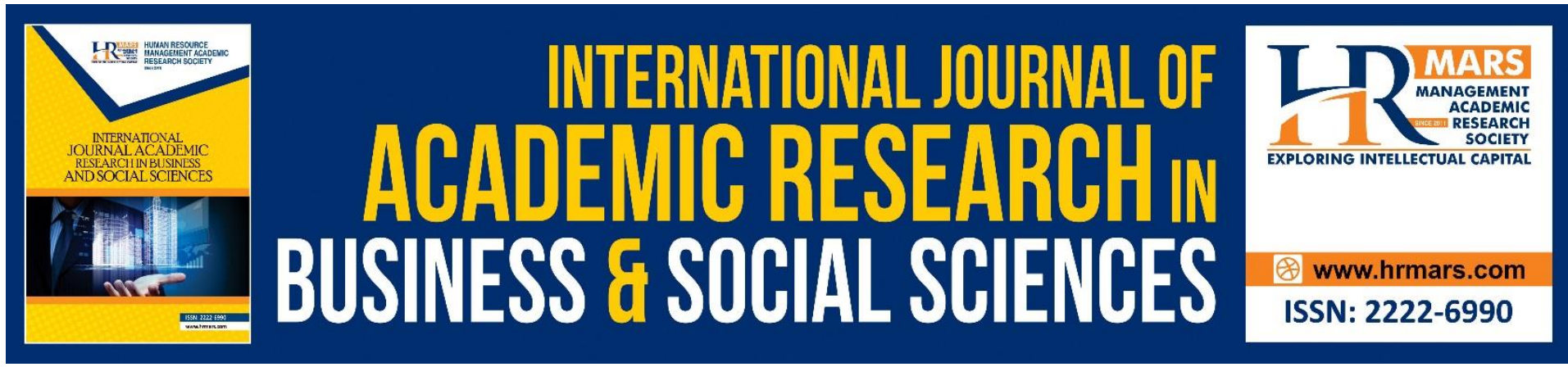

\title{
The Nexus of Pondok Pesanten and Quadruple Helix Approach to Enhance Local Capacity in Jember, Indonesia
}

\author{
${ }^{1}$ Suyatno Ladiqi, ${ }^{2}$ Anas Mohd Yunus, ${ }^{2}$ Mohamad Zaidin Bin \\ Mat@ Mohamad, ${ }^{2}$ Najihah Binti Abd Wahid, ${ }^{2}$ Mohd. Shafiee \\ Bin Hamzah \\ ${ }^{1}$ Faculty of Law \& International Relations, ${ }^{2}$ Faculty of Islamic Contemporary, Universiti \\ Sultan Zainal Abidin 21300 Terengganu, Malaysia
}

\begin{abstract}
Pondok Pesantren (Islamic Boarding School) is constructed as a traditional religious learning institution famous and more systemic. It became very influential in the pre-colonial and the occupation period. Associated with the maintenance of the local value but syllabus each school pondok pesantren was not uniform. Pondok Pesantren functions to facilitate collective action in a determined pattern so that it functions not only as an organization but also as a social institution. Local institutions, especially in their capacity as social institutions, are matured through a social learning process, which essentially works while learning so that local wisdom will eventually develop. Increasingly sustainable local impartiality will function as an empowerment instrument for both internal and external relations. Internally, the local institutional capacity will facilitate community development in the process of selfmanagement, including as a means of decision making and resource management, while the external function as a representative of the community will work with various stakeholders. This is a reflection of the capacity of local communities to build networks and increase the bargaining position of other stakeholders (Soetomo, 2011). In particular relations with local government are very crucial that influenced vice versa.

All politics is local. After the fall of Suharto's regime, Indonesia entered a democratic state that gives autonomy and decentralization at the local level. Local Governance becomes a big issue in political life in particular arrangement all of the power to distribute resources toward people. The problem at the local level regarding increasing local capacity can be approached by the relations of government, industry sectors, university communities, and citizens. This approach namely the Quadruple Helix Model which focuses on these relations is seen as a key actor promoting approach to innovation through which strategy development and decision making are exposed to feedback from key stakeholders, resulting in socially accountable policies and practices. This model can encourage the implementation of local governance because the relationship between the government, market, and citizens (governance) can be maintained. Handling the issue of radicalism can be managed through this relationship by
\end{abstract}


creating programs and policies that can significantly reduce the influence of radicalism at the local level, such as cooperation between Pondok Pesantren, local government, university communities, and industry sectors.

This paper focuses on the relations between government, university communities, industry sectors, and Pondok Pesantren (Ponpes) to handle the influence of radicalism, with a specific reference for East Java province, in particular in Jember district (Kabupaten) as a case study. It tries to answer the following questions. 1) Why do we need to encourage Sekolah Pondok to increase relations with the Local government, industry sector, and university community? 2) What kind of program can enhance local capacity? 3) How are relations between Pondok pesantren, university, local government, and industry sectors?

Keywords: Pondok Pesantren, Quadruple Helix Model.

\section{Methodology}

This paper will use qualitative data collection tools, by using library research and discussion with experts and academics, in particular with the stakeholders of Sekolah Pondok in Jember, East Java, Indonesia. Having collaboration with the host institution to get access to data and to meet relevant academics is very important to support this project.

\section{Discussion}

Etzkowitz and Leydesdorff (1995) proposed the model of a Triple Helix (TH) of universityindustry-government relations for explaining structural developments in knowledge-based economies. In a knowledge-based economy-as against a political economy-the structure of society is continuously upset by transformations which originate from technoscience. For Etzkowitz and Leydesdorff (2000: 15) the "university-industry-government relations" are of crucial importance, with universities representing a core institution in the knowledge society: "The university can be expected to remain the core institution of the knowledge sector" (Etzkowitz \& Leydesdorff, 2000:117-118). Furthermore: "The Triple Helix thesis states that the university can play an enhanced role in innovation in increasingly knowledge-based societies" (Etzkowitz \& Leydesdorff, 2000:109). Research and teaching are central functions of universities.

Some conclusions of Triple Helix are (Etzkowitz \& Leydesdorff, 2000:118-119): (1) the nationstate no longer defines the only level for arrangements between government and industrial sectors; (2) profit represents an important driving force; (3) successful innovations change the "landscape", meaning the "opportunity structure" for institutions; (4) the "human capital factor" gains in importance; (5) tensions create a "dynamics for the system", so they do not necessarily have to be resolved; (6) the communication density within each helix is higher than across the helices, however, in connection to the advancement of systems, the crosshelix communication flow should increase substantially.

The metaphor of a Triple Helix more or less invites proposals to extend the model to more than three helices. In response to a discussion that focused on bringing "society" or "the public" back into the model as a fourth helix, Leydesdorff \& Etzkowitz (2003) argued that the helices represent specialization and codification in function systems which evolve from and within civil society. The "Quadruple Helix" (four-helix) model adds to government, universities (higher education) and the economy as further fourth helix the "public", more precisely be defined as the "media-based and culture-based public": "This fourth helix associate with 
'media', 'creative industries', 'culture', 'values', 'lifestyles', and perhaps also the notion of the 'creative class' (a term, coined by Florida, 2004; Maroniti et al., 2013). This fourth helix also could be titled or described as the media-based, culture-based and values-based public. The Quadruple Helix is analytically broader than the Triple Helix, thus can be used for research questions outside the core focus of Triple Helix. The Quadruple Helix reflects on phenomena such as the "media-based democracy" or a "multimedia information society" (Plasser, 2002). The Quadruple Helix model adds to the "university-industry-government relations" the fourth helix of a "media-based and culture-based public" that also includes values and different value systems.

The existence of Pondok Pesantren can be seen as a "media-based and culture-based public" as a local institution that bridges as a media communication between residents and local state stakeholders. The role of the Kyai as the leader of Pondok Pesantren is very crucial at this level because the Kyai is not only the leader of the institution but also an informal community figure whose existence is highly respected by the state. Pondok Pesantren is also an arena for cultural encounters of various students who come to study and a conveyor of local culture and Islam into a dynamic combination (culture-based public). It is in this context that this paper sees that the existence of a boarding school represents the fourth helix so that the Quadruple Helix approach is very suitable for analyzing the role of Islamic boarding schools in increasing local capacity.

Local capacity is important at the local level in particular in the Quadruple Helix approach implementation. Capacity is assessed concerning goals of production and allocative efficiency. Capacity for production efficiency is manifested in the presence of a performance-oriented government. It requires that the government have the tools to optimize the use of resources in the production or provision process. Capacity for allocative efficiency is manifested in the presence of a customer-oriented government. It involves the existence and adequate functioning of mechanisms through which the community can voice demands, channels by which authorities can translate those demands into actions and instruments for government accountability. The presumption is that failure in any of these elements would diminish the capacity to achieve the allocation of public resources that maximizes welfare (Fizbein, 1997). In explaining the meaning of local capacity, Fizbein emphasizes the government's more important position. However, when combined with the Quadruple Helix approach, it will be seen how the dynamics of this relationship will determine the ability to increase local capacity. This paper uses Pondok Pesantren as the center of the discussion, so their role will certainly have a strong role in the successful implementation of the Quadruple Helix. At least this approach can map the weaknesses and strengths of the relationship between institutions at the local level.

\section{Result}

There are several programs based on the collaboration in the Quadruple Helix approach. It's just that the relationship that took place was not comprehensive. It could be said in a partial form. This explains why the Quadruple Helix approach is so important if it is carried out holistically. Because the programs that have been running even though in the context are not comprehensive, it can be said that they can increase local capacity which is quite good. This is where the Pondok Pesantren plays an important role in increasing the capacity of local capacities that can tie the overall relationship together. 
The Pondok Pesantren Al Qodiri, for example, can collaborate with the industrial sector by producing Mineral Water products that are sold to the public, namely Al Qodiri Mineral Water. Pondok Pesantren Miftahul Ulum Jember, together with other Islamic boarding schools in East Java, namely the Pondook Pesantren Bayt Al Hikmah, Pondok Pesantren the Salafiyah, the Pondok Pesantren Minh Knab Thullab, BPUI Minh Knitting Thullab (Minh Knitting Thullab Krikilan) - Banyuwangi, Pondok Pesantren Mabdiul - Probolinggo, Pondok Pesantren Maarif, and Al-Falah Islamic Boarding School, Ploso - Kediri, participated in a program created by the central government in the form of "Hipmi Goes to Pesantren". The program aims to drive entrepreneurship among pondok pesantren residents, especially students (Bisnis.com, 2020).

The relationship with the local government is carried out by the Pondok Pesantren in "Bela Negara" (the State Defense) program. Socialization of the values of the state and citizenship is carried out to foster awareness of the importance of loving the country. The Pondok Pesantren Shofa Marwa is conducting this program in collaboration with the police, army, and district government institutions. In the field of education, the Pondok Pesantren Shofa Marwa also conducts regular discussions and teaching and learning processes with the Jember State Islamic Institute (IAIN) and universities in Malaysia, such as Sultan Zainal Abidin University (UniSZA) and the Malaysian International Islamic University (UIAM).

From the examples of cooperation carried out by several Pondok Pesantren, it seems that there has not yet emerged comprehensive cooperation as the Quadruple Helix approach suggests. Pondok Pesantren, which collaborates with the government and the industrial sector in the Hipmi Goes to Pesantren program, does not include university elements in it. Collaboration with the education sector as the Pondok Pesantren Shofa Marwa is not accompanied by comprehensive cooperation with other sectors. Even if there is cooperation with the government, it is only bilateral and the activities are separate from programs that are established with universities or the industrial sector. It can be said that the role of Pondok Pesantren is very important to initiate this comprehensive relationship. Pondok Pesantren can be a trigger because institutionally it reflects "media-based and culture-based public" as the fourth Helix. This function is very crucial in increasing local capacity. However, political activities (Bela Negara/State Defense), economics (Hipmi Goes to Campus or Air Mineral AlQodiri), social and educational activities (seminars and discussions and teaching) make a treasure trove of knowledge and activities that can be said to be important assets to be improved as a whole in the context of the Quadruple Helix model. If it is done well, local capacity will be easy to achieve.

\section{Conclusion}

The pivotal role of Pondok Pesantren has long been taking place in local communities. Its relationship with the local government also determines local capacity. Along with the development of the era when the industrial world entered people's lives with a very strong appeal to be involved in it, the classical relationship changed. The industrial sector becomes important concerning Pondok Pesantren and local government. Along with these developments, the existence of universities cannot be ignored. Their analytical and research capabilities are needed to improve the relationship between the three sectors. So the Quadruple Helix becomes an effective approach to portray local communities in the context of increasing local capacity. What happened in Jember the Quadruple Helix approach has not been fully implemented. This is a great opportunity for Pondok Pesantren to initiate increased relations between these four sectors. With this, the central role of Pondok Pesantren which 
has been running for a long time is now very important, because it is not only able to be the glue for the three "helix" but also, in turn, will increase the local capacity which is much needed

\section{Acknowledgement}

This paper is a part of research project of Special Research Grant Scheme (SRGS) entitled INTEGRASI MANHAJ PENGAJIAN PONDOK DAN UNIVERSITI DI MALAYSIA DAN INDONESIA (UniSZA/FKI/2018/04) that is funded by Universiti Sultan Zainal Abidin in Terengganu, Malaysia managed by Center For Research Excellence and Incubation Management (CREIM), Universiti Sultan Zainal Abidin in Terengganu, Malaysia

\section{References}

Beyer, C. (2010). Counter Terrorism and International Power Relations: The EU, ASEAN and Hegemonic Global Governance. I.B. Tauris. London.

Bisnis.com. (2018). "Ritel Modern Umat Mart Diresmikan Presiden Pekan Ini". https://ekonomi.bisnis.com/read/20180510/12/793535/ritel-modern-umat-martdiresmikan-presiden-pekan-ini. Downloaded 20 July 2020.

Carayannis, E. G., \& Campbell, D. F. J. (2010). 'Triple Helix, Quadruple Helix and Quintuple Helix and how do knowledge, innovation and the environment relate to each other? A proposed framework for a trans-disciplinary analysis of sustainable development and social ecology'. International Journal of Social Ecology and Sustainable Development, 1(1), 41-69.

Etzkowitz, H. , Leydesdorff, L. (1995). "The Triple Helix-university-industry-government relations: a laboratory for knowledge-based economic development". EASST Review 14:14-19

Etzkowitz, H., \& Leydesdorff, L. (2000). 'The Dynamics of Innovation: From National Systems and "Mode 2" To A Triple Helix of University-Industry-Government Relations'. Research Policy, 29, 109-123.

Etzkowitz, H. (2003). 'Research Groups as "Quasi-Firms": The Invention of the Entrepreneurial University'. Research Policy, 32, 109-121. doi:10.1016/S00487333(02)00009-4.

Etzkowitz, H. (2008). The Triple Helix: University-Industry-Government Innovation in Action. Routledge. London.

Fiszbein, A. (1997). "The Emergence of Local Capacity: Lessons from Colombia". World Development, Vol. 25, No. 7, pp. 1029-1043.

Florida, R. (2004). The Rise of the Creative Class: And How It's Transforming Work, Leisure, Community, and Everyday Life. Cambridge, MA: Basic Books.

Goss, S. (2001). Making Local Governance Work. Palgrave. New York.

Hafez, K. (2010). Radicalism and Political Reform in the Islamic and Western Worlds. Cambridge University Press. Cambridge.

Hordijk, M. (2012). "Citizenship, Local Governance and Democracy". In Nicky Pouw and Isa Baud. Local Governance and Poverty in Developing Nations. Routledge. New York.

Leydesdorff, L., Etzkowitz, H. (2003). 'Can "the public" be considered as a fourth helix in university-industry-government relations?' Report of the fourth Triple Helix conference. Sci Public Policy 30(1), 55-61. 
Maroniti, K., Stamou, A. G., Dinas, K. D., \& Griva, E. (2013). The sociolinguistic style of cartoons: The case of the TV movie Merry Madagascar. Multilingual Academic Journal of Education and Social Sciences, 1(2), 59-75.

Patrick, C. (2015). The Rise of Islamic State: ISIS and the New Sunni Revolution. Verso. London.

Plasser, F., \& Plasser, G. (2002). Global Political Campaigning. A Worldwide Analysis of Campaign Professionals and Their Practices. Westport, CT: Praeger.

Stoker, G. (2003). Transforming Local Governance: from Thatcherism to New Labour. Basingstoke,UK. Palgrave Macmillan. 